\title{
Maternal exposure to nanoparticulate titanium dioxide during the prenatal period alters gene expression related to brain development in the mouse
}

\author{
Midori Shimizu1ㄴ, Hitoshi Tainaka², Taro Oba1', Keisuke Mizuo², \\ Masakazu Umezawa ${ }^{1}$ and Ken Takeda*1,2
}

Address: ${ }^{1}$ Department of Hygienic Chemistry, Faculty of Pharmaceutical Sciences, Tokyo University of Science, Chiba 278-8510, Japan and 2Research Center for Health Sciences of Nanoparticles, Research Institute for Science and Technology, Tokyo University of Science, Yamazaki 2641, Noda-shi, Chiba 278-8510, Japan

Email: Midori Shimizu - j3107640@ed.noda.tus.ac.jp; Hitoshi Tainaka - htainaka@rs.noda.tus.ac.jp; Taro Oba - j3108620@ed.noda.tus.ac.jp; Keisuke Mizuo - kmizuo@rs.noda.tus.ac.jp; Masakazu Umezawa - j3108703@ed.noda.tus.ac.jp; Ken Takeda* - takedak@rs.noda.tus.ac.jp

* Corresponding author

Published: 29 July 2009

Particle and Fibre Toxicology 2009, 6:20 doi:10.1186/1743-8977-6-20
Received: I April 2009

Accepted: 29 July 2009

This article is available from: http://www.particleandfibretoxicology.com/content/6/1/20

(C) 2009 Shimizu et al; licensee BioMed Central Ltd.

This is an Open Access article distributed under the terms of the Creative Commons Attribution License (http://creativecommons.org/licenses/by/2.0), which permits unrestricted use, distribution, and reproduction in any medium, provided the original work is properly cited.

\begin{abstract}
Background: Nanotechnology is developing rapidly throughout the world and the production of novel man-made nanoparticles is increasing, it is therefore of concern that nanomaterials have the potential to affect human health. The purpose of this study was to investigate the effects of maternal exposure to nano-sized anatase titanium dioxide $\left(\mathrm{TiO}_{2}\right)$ on gene expression in the brain during the developmental period using cDNA microarray analysis combined with Gene Ontology (GO) and Medical Subject Headings (MeSH) terms information.

Results: Analysis of gene expression using GO terms indicated that expression levels of genes associated with apoptosis were altered in the brain of newborn pups, and those associated with brain development were altered in early age. The genes associated with response to oxidative stress were changed in the brains of 2 and 3 weeks old mice. Changes of the expression of genes associated with neurotransmitters and psychiatric diseases were found using MeSH terms.
\end{abstract}

Conclusion: Maternal exposure of mice to $\mathrm{TiO}_{2}$ nanoparticles may affect the expression of genes related to the development and function of the central nervous system.

\section{Background}

Nanotechnology and the production of novel man-made nanoparticles are increasing worldwide. Titanium dioxide $\left(\mathrm{TiO}_{2}\right)$ has a high level of photocatalytic activity, and can be used for air and water purification and self-cleaning surfaces [1]. The activity level of nanoparticles is higher than that of bulk-sized particles $[2,3]$. $\mathrm{TiO}_{2}$ has the potential to produce reactive oxygen species (ROS) in its photocatalysis [1] and its possibly detrimental health effects are of concern. It has been reported that a mixture of anatase and rutile $\mathrm{TiO}_{2}$ nanoparticles induced cytotoxicity against human lung epithelial cells (BEAS-2B), even in the absence of photoactivation [4]. Sayes et al. [5] showed that anatase $\mathrm{TiO}_{2}$ nanoparticles, which can generate more ROS than rutile $\mathrm{TiO}_{2}$ particles, exhibited a higher level of cytotoxicity against human dermal fibroblasts and human lung epithelial cells (A549) than rutile $\mathrm{TiO}_{2}$ nanoparticles. 
The small size of nanoparticles can bestow unique translocational properties $[6,7]$. It has been reported that nanosized elemental carbon particles $(36 \mathrm{~nm})$ inhaled by adult rats were translocated into extrapulmonary organs, such as liver [8]. A subsequent study showed that intranasally instilled carbon black nanoparticles can be translocated to the central nervous system, including cerebrum, cerebellum, and olfactory bulb via the olfactory nerve [9]. In a recent study, Takeda et al. [10] found that $\mathrm{TiO}_{2}$ nanoparticles administrated subcutaneously to pregnant mice were transferred from the mother to the fetal brain, and induced apoptosis in the mitral cells of the olfactory bulb of mice exposed maternally to the nanoparticles. Fetal brains are easily affected by blood-borne substances, including nano-sized materials, to a much greater extent than adult brains because the development of the bloodbrain barrier in the fetal brains is incomplete [11]. Taking these observations into consideration, functional alterations of the central nervous system induced by maternal exposure to nanoparticles need to be investigated. To analyze the effect of maternal exposure to $\mathrm{TiO}_{2}$ nanoparticles on the early stages of development of the brain, we used microarray technology and gene expression profiles by functional annotation of genes using Gene Ontology (GO) terms and Medical Subject Headings (MeSH) terms.

\section{Methods}

\section{Titanium dioxide nanoparticles}

$\mathrm{TiO}_{2}$ nanopowder (particle size $2570 \mathrm{~nm}$; surface area $2025 \mathrm{~m}^{2} / \mathrm{g}$; crystal form anatase) was purchased from Sigma-Aldrich Japan Inc. (Tokyo, Japan) and used as $\mathrm{TiO}_{2}$ nanoparticles. The nanopowder was suspended in saline (Otsuka Pharmaceutical Factory Inc., Tokushima, Japan) with $0.05 \%(\mathrm{v} / \mathrm{v})$ Tween 80 and sonicated for more than 30 minutes immediately before administration.

\section{Animals and treatments}

Pregnant ICR mice, purchased from Japan SLC Inc. (Shizuoka, Japan), were housed in a room under controlled temperature $\left(23 \pm 1^{\circ} \mathrm{C}\right)$, humidity $(55 \pm 5 \%)$ and light (12 h light/12 h dark cycle with light on at 8:00 a.m.) with ad libitum access to food and water. Pregnant mice were transported carefully to minimize stress factors by Sankyo Labo Service Co., Inc (Tokyo, Japan). All animals were handled in accordance with institutional and national guidelines for the care and use of laboratory animals.

A $100 \mu \mathrm{L}$ volume of $\mathrm{TiO}_{2}$ suspended at $1 \mu \mathrm{g} / \mu \mathrm{L}$ was injected subcutaneously into pregnant mice $(n=15)$ on gestational days $6,9,12$, and 15 for the exposure group, while $100 \mu \mathrm{L}$ of vehicle alone was injected into pregnant mice $(n=14)$ as a control group. Brain tissue was obtained from male fetuses on embryonic day (ED) 16 ( $n$ $=8 /$ group $)$ and from male pups on postnatal days $2(n=$ 10/group), 7 ( $n=10 /$ group), 14 ( $n=9$ /group), and 21 ( $n$ $=9$ /group).

\section{Total RNA extraction}

Whole brains were immediately frozen in liquid nitrogen and kept at $-80^{\circ} \mathrm{C}$. Frozen tissue was homogenized and extracted with Isogen (Nippon Gene Co., Ltd., Tokyo, Japan) while well stirred by a Vortex-Genie 2 (Scientific Industries, Tokyo, Japan). Total RNA was isolated according to the manufacture's protocol and suspended in TE buffer (10 mM Tris-HCl, pH 8.0, 1 mM EDTA).

\section{Complementary DNA microarray analysis}

RNAs for microarray analysis were pooled for each group, purified using the RNeasy Micro Kit (Qiagen, Hilden, Germany) and reverse-transcribed to yield complementary DNA (cDNA) labeled with the fluorescent dye Cy3 or Cy5 using the SuperScript Indirect cDNA Labeling Core Kit (Invitrogen, CA, USA) and the SuperScript Indirect cDNA Labeling System Purification Kit (Invitrogen). Cy3- and Cy5-labeled samples were purified using the CyScribe GFX Purification Kit (GE Healthcare Bio-Sciences, Little Chalfont, UK). The generated targets were mixed and subjected to hybridization to an NIA mouse $15 \mathrm{~K}$ Microarray v2.0 (AGC Techno Glass Co. Ltd., Chiba, Japan) consisting of 16,192 gene probes. Microarrays were scanned with two different photomultiplier sensitivities by a ScanArray (Packard BioChip Technologies, MA, USA). The scanner output images were normalized and signal quantification was performed using ScanArray Express (Perkin Elmer, MA, USA) and TIBCO Spotfire (TIBCO Software Inc., CA, USA). Normalization was used so that the overall intensity ratio of Cy3 and Cy5 was equal to 1 . Statistical analysis was done with analysis of variance (ANOVA) and the level of statistical significance was set at $P<0.05$.

\section{Functional analysis of microarray data with gene annotation}

A total of $37 \mathrm{GO}$ terms and $66 \mathrm{MeSH}$ terms associated with anatomy, brain development and associated peptides, neurotransmitters, hormones, behavior and psychological phenomena, brain related disorders, oxidative stress, inflammation, and cell death were selected (Table 1, 2); and 2838 and 3625 genes were annotated by GO and MeSH terms, respectively, using the gene reference database PubGene (https://server.pubgene.com/online/ PubGene/, Pub Gene AS, Oslo, NOR). These annotations were updated in April, 2008. The genes for which upregulation and downregulation were detected were categorized with GO and MeSH terms. The enrichment factor for each category was defined as $(n f / n) /(N f / N)$, where $n f$ is the number of differentially expressed genes within the category, $n$ is the total number of genes within that same category, $N f$ is the number of differentially expressed genes on the entire microarray, and $N$ is the total number of genes on the microarray. Statistical analysis was performed using Fisher's exact test with hypergeometric distribution and the level of statistical significance was set at $P<0.05$. 
Table I: List of GO terms selected for gene annotation

\begin{tabular}{|c|c|c|}
\hline Category & & GO term \\
\hline \multirow[t]{6}{*}{ biological process } & developmental process & $\begin{array}{l}\text { brain development } \\
\text { forebrain development } \\
\text { midbrain development } \\
\text { hindbrain development } \\
\text { generation of neurons } \\
\text { glial cell differentiation }\end{array}$ \\
\hline & biological regulation & $\begin{array}{l}\text { cell death } \\
\text { apoptosis } \\
\text { neuron apoptosis } \\
\text { activated T cell apoptosis } \\
\text { B cell apoptosis } \\
\text { negative regulation of neuron apoptosis } \\
\text { apoptotic mitochondrial changes } \\
\text { induction of programmed cell death } \\
\text { induction of apoptosis } \\
\text { anti-apoptosis } \\
\text { glucocorticoid biosynthesis } \\
\text { glucocorticoid metabolism } \\
\text { neurotransmitter metabolism } \\
\text { neurotransmitter transport }\end{array}$ \\
\hline & multicellular organismal process & $\begin{array}{l}\text { cognition } \\
\text { learning and, or memory }\end{array}$ \\
\hline & regulation of biological process & $\begin{array}{l}\text { regulation of glial cell differentiation } \\
\text { regulation of nerve growth factor receptor activity } \\
\text { regulation of glucocorticoid biosynthesis process }\end{array}$ \\
\hline & cellular process & $\begin{array}{l}\text { mitochondrial fission } \\
\text { mitochondrial fusion }\end{array}$ \\
\hline & response to stimulus & $\begin{array}{l}\text { response to oxidative stress } \\
\text { response to reactive oxygen species } \\
\quad \text { response to superoxide } \\
\text { superoxide metabolism } \\
\text { glutathione biosynthesis } \\
\text { glutathione metabolism }\end{array}$ \\
\hline molecular function & & $\begin{array}{l}\text { motor activity } \\
\text { superoxide dismutase activity } \\
\text { glucocorticoids receptor activity } \\
\text { brain derived neurotrophic factor binding }\end{array}$ \\
\hline
\end{tabular}

\section{Results}

\section{Analysis of cDNA microarrays}

In the maternal $\mathrm{TiO}_{2}$ exposure group, the expression levels of 462 genes were changed significantly in the brain of the fetus at ED 16 (upregulation 229 genes; downregulation 233 genes), and those of 864 (upregulation 234; downregulation 630), 417 (upregulation 351; downregulation 66), 738 (upregulation 450; downregulation 288), and 1887 (upregulation 613; downregulation 1274) were changed significantly in the brain of offspring $2,7,14$, and 21 days old, respectively (Table 3 ). The number of genes differentially expressed between groups was increased remarkably in the brain of 21 days old pups.

\section{Functional categorization of microarray data}

Of the genes expressed differentially in the maternal $\mathrm{TiO}_{2}$ exposure group, 3, 2, 8, and $4 \mathrm{GO}$ categories were enriched significantly in the brain at $2,7,14$, and 21 days after birth, respectively (Table 4), while 6, 2, 36, and 28 MeSH categories were enriched significantly at 2, 7, 14, and 21 days after birth (Additional file 1). Eight MeSH categories were also enriched significantly in the fetal brain 
Table 2: List of MeSH terms selected for gene annotation

\begin{tabular}{|c|c|c|}
\hline Category & MeSH term & \\
\hline \multirow[t]{4}{*}{ Anatomy } & Blood Brain Barrier & Neurons \\
\hline & Microglia & Olfactory Receptor Neurons \\
\hline & Mitochondria & Synapses \\
\hline & Neuroglia & \\
\hline \multirow[t]{7}{*}{ Diseases } & Alzheimer Disease & Inflammation \\
\hline & Anxiety Disorders & Learning Disorders \\
\hline & Attention Deficit Disorder & Memory Disorders \\
\hline & with Hyperactivity & Mitochondrial Disease \\
\hline & Autistic Disorder & Neurogenic Inflammation \\
\hline & Cognition Disorders & Parkinson Disease \\
\hline & Epilepsy & Schizophrenia \\
\hline \multirow[t]{5}{*}{ Psychiatry and Psychology } & Affective Symptoms & Memory \\
\hline & Anxiety & Memory, Short-Term \\
\hline & Cognition & Motivation \\
\hline & Depression & Stress, Psychological \\
\hline & Emotions & \\
\hline \multirow[t]{12}{*}{ Chemicals and Drugs } & Apoptosis Inducing Factor & Anti-Anxiety Agents \\
\hline & Apoptosis Regulatory Proteins & Glutathione \\
\hline & Caspases & Glutathione Peroxidase \\
\hline & Brain Derived Neurotrophic & Glutathione Synthase \\
\hline & Factor & Inflammation Mediators \\
\hline & Glial Cell Line-Derived & Neuronal Apoptosis- \\
\hline & Neurotrophic Factor & Inhibitory Protein \\
\hline & Nerve Growth Factor & Nitric Oxide \\
\hline & Hormones & Reactive Oxygen Species \\
\hline & Glucocorticoids & Superoxides \\
\hline & Growth Hormone & Superoxide Dismutase \\
\hline & Thyroid Hormones & \\
\hline \multirow[t]{7}{*}{ Neurotransmitters } & Acetylcholine & Norepinephrine \\
\hline & Dopamine & Serotonin \\
\hline & Epinephrine & Receptors, \\
\hline & gamma-Aminobutyric Acid & Neurotransmitter \\
\hline & Glutamic Acid & Neuropeptides \\
\hline & & Neurotransmitter Uptake \\
\hline & & Inhibitors \\
\hline \multirow[t]{4}{*}{ Biological Science } & Apoptosis & Motor Activity \\
\hline & Cell Death & Neural Plasticity \\
\hline & Gene, Mitochondrial & Oxidative Stress \\
\hline & Lipid Peroxides & \\
\hline
\end{tabular}

at ED 16 (Additional file 1). The largest group of GO categories enriched was those related to cell death 221 days after birth; 121 and 64 genes linked to apoptosis at 2 and 7 days after birth, respectively, and 92 and 173 genes linked to "cell death" were identified at 14 and 21 days after birth. "Brain development" was also a large category at 2 (34 genes) and 14 (43 genes) days after birth. GO categories related to oxidative stress, such as "superoxide dismutase activity", were also enriched significantly at 14 and 21 days after birth. The largest MeSH categories enriched were "Mitochondria" at ED 16 (31 genes) and 2 days (56 genes) after birth and "Apoptosis" at 14 (118 genes) and 21 (230 genes) days after birth. The "Mitochondria" category was persistently enriched at 14 (60 genes) and 21 (109 genes) days after birth. MeSH categories related to oxidative stress, such as "Glutathione", "Lipid Peroxidation", and "Reactive Oxygen Species", were also enriched significantly at ED 16 and 14 and 21 days after birth. MeSH categories related to inflammation and neurotransmitters including "Epinephrine", "Norepinephrine", "Serotonin", and "Glutamic Acid" were also highly enriched at 14 and 21 days after birth. 
Table 3: The number of genes differentially expressed in maternal $\mathrm{TiO}_{2}$ exposure group

\begin{tabular}{llll}
\hline Age & Upregulated & Downregulated & Total \\
\hline Embryonic day 16 & 229 & 233 & 462 \\
\hline 2 days old & 234 & 630 & 864 \\
\hline 7 days old & 351 & 66 & 417 \\
\hline 14 days old & 450 & 288 & 738 \\
\hline 21 days old & 613 & 1274 & 1887 \\
\hline
\end{tabular}

\section{Discussion}

Nanoparticles have a high level of reactivity with biological tissue, since they have a large specific surface area $[6,7]$. It has been reported that fullerenes, which are manufactured carbon nanoparticles, induce oxidative stress in the brain of juvenile largemouth bass [12]. Tin-Tin-Win-Shwe et al. [13] showed that intranasal instillation of ultrafine carbon black $(14 \mathrm{~nm})$ to mice induced a higher level of expression of cytokines and chemokines in the olfactory bulb compared to those induced by the same mass of carbon black $(95 \mathrm{~nm})$. The particles used in the exposed pregnant mice group can enter the circulatory system and can transfer to and damage the fetus. Sugamata et al. [14] reported that the cytoplasmic granules of granular perithe-

Table 4: Significantly enriched GO categories in maternal exposure group vs. control group

\begin{tabular}{lll}
\hline GO term & Enrichment factor & P value \\
\hline $\begin{array}{l}\text { Embryonic day I6 } \\
\text { (None) }\end{array}$ & \\
2 days old & & \\
$\quad$ apoptosis & 1.04 & \\
brain development & 1.21 & .05 \\
$\quad$ motor activity & 1.80 & .04 \\
$\mathbf{7}$ days old & & .02 \\
apoptosis & 1.11 & \\
glial cell differentiation & 5.14 & .01 \\
I4 days old & & .02 \\
$\quad$ activated T cell apoptosis & 3.75 & \\
brain development & 1.48 & .02 \\
cell death & 1.08 & .00 \\
induction of apoptosis & 1.28 & .04 \\
motor activity & 1.58 & .01 \\
$\quad$ response to oxidative stress & 1.70 & .05 \\
$\quad$ response to reactive oxygen species & 1.53 & .01 \\
$\quad$ superoxide dismutase activity & 2.22 & .05 \\
2I days old & & .01 \\
anti-apoptosis & 1.58 & .02 \\
cell death & 1.03 & .04 \\
glutathione biosynthesis & 1.62 & .04 \\
superoxide dismutase activity & 1.75 & .01 \\
\hline
\end{tabular}

lial cells contain particles of diesel exhaust (DE) and degenerate in both the cerebral cortex and the hippocampus of mice exposed prenatally to DE. A later study [15] showed that maternal DE exposure alters the levels of monoamines and their metabolites in brains and spontaneous motor activity in male mice. Since $\mathrm{TiO}_{2}$ was detected in the brain of mice maternally exposed to $\mathrm{TiO}_{2}$ nanoparticles [10], which is the material used in this study, microarray was applied to the analysis of the effects of maternal exposure to $\mathrm{TiO}_{2}$ nanoparticles on the brain of neonatal mice.

In the present study, we used only male fetuses and pups for analysis because the prevalence of some psychiatric disorders in childhood, such as autism and attention deficit hyperactivity disorder, is higher in men than in women. The results of the microarray analysis showed changes in expression of hundreds of genes in the brain at ED 16, and at 2, 7, 14, and 21 days after birth. To interpret the large amount of data generated, functional categorization using GO terms and MeSH terms were performed, which identified potentially important categories on the basis of both a high enrichment factor $(>1.00)$ and statistical significance $(P<0.05)$. MeSH is a controlled vocabulary thesaurus produced by the National Library of Medicine and used for indexing, cataloging, and searching for biomedical and health-related information and documents. Although most researchers use GO for providing annotation to genes, MeSH terms are proposed to be a useful complementary tool for interpretation of microarray data [16]. A subsequent report [17] showed that the use of MeSH has the advantage of producing anatomical and disease information with respect to the genes of interest. In the present study, genes were annotated with the terms related to anatomy, brain development, brainrelated disorders, those associated with nanotoxicology (oxidative stress $[6,7,12]$ and inflammation $[6,7,13]$ ), and those associated with the effects of maternal exposure to $\mathrm{DE}$ or $\mathrm{TiO}_{2}$ nanoparticles (hormones [18], behavior and neurotransmitters $[15,18]$, and cell death $[10,14,19])$ for analysis.

As a result, GO terms associated with development of brain were extracted at 2 and 14 days after birth, those associated with cell death, including apoptosis, were extracted 2 to 21 days after birth, and those associated with response to oxidative stress were extracted at 14 and 21 days. Brain development is regulated by neurotrophins such as nerve growth factor, brain-derived neurotrophic factor [20], and glial cell line-derived neurotrophic factor [21], and hormones including growth hormone [22] and thyroid hormone $[23,24]$. Analysis using MeSH terms showed that alteration of these factors that can lead to abnormal development of the central nervous system was induced by maternal exposure to $\mathrm{TiO}_{2}$ nanoparticle. It has 


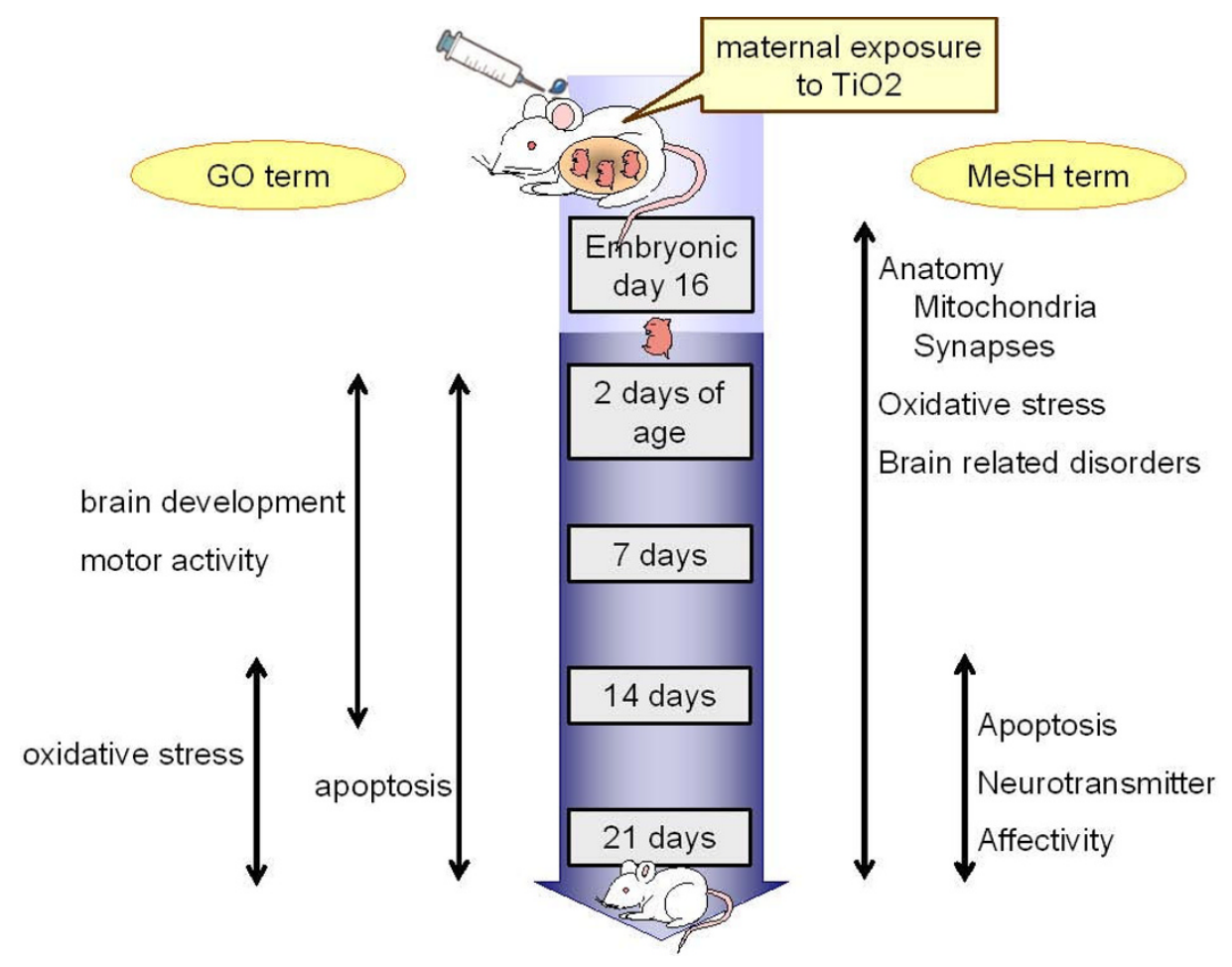

Figure I

Summary of the extracted terms with genes differentially expressed in the maternal $\mathrm{TiO}_{2}$ exposure group.

been reported that neuronal cell death, including apoptosis, is essential for elimination of neurons and axons to make correct synaptogenesis in the early stage of brain development $[25,26]$. The result of functional analysis suggested that disruption of these processes can be caused by maternal exposure to $\mathrm{TiO}_{2}$ nanoparticles.

It has been reported that the changes of environment surrounding pregnant mice cause abnormal level of neurotransmitters in the brain of the offspring. Meyer et al. [27] reported that maternal immune challenge by the viral mimic polyriboinosinic-polyribocytidilic acid causes abnormal fetal dopaminergic development, which is similar to a schizophrenic symptom. Maternal stress also induces altered expression of genes related to the dopaminergic system in the midbrain and causes hyperactivity in adult offspring [28]. The results that MeSH terms associated with neurotransmitters and motor activity were extracted suggest that maternal exposure to $\mathrm{TiO}_{2}$ nanoparticles causes abnormal levels of neurotransmitters that can lead to altered motor activity.

As for MeSH terms, those associated with diseases were extracted in the functional analysis. Some diseases such as autistic disorder, epilepsy, and learning disorders, occur in childhood, and although Alzheimer's disease, schizophrenia, and Parkinson's disease arise mainly in adulthood or old age, related MeSH terms were extracted in the results from infant mice of mothers exposed to $\mathrm{TiO}_{2}$. In the early 1990s, Dr David Barker J.P. stated that fetal undernutrition increases the incidence of cardiovascular disease in adult life [29]. Subsequent studies showed the environment that the fetus senses indirectly through the mother can be linked to other diseases in adulthood, and proposed a hypothesis of "early developmental origins of adult disease" [30]. The results of the present study suggest that maternal exposure to nanoparticles can alter gene expression in the neonatal period and might cause the onset of psychiatric disorders even in adulthood. However, the present study did not show how the maternal response to the nanoparticles altered the mother's behavior toward the pups and how this in turn altered gene expression. Further investigations are needed to clarify the critical factor for the gene expression change. Moreover, the changes caused by maternal exposure to $\mathrm{TiO}_{2}$ nanoparticles should not be limited to the brain. Our published [10] and unpublished data suggest that other organ systems are also affected.

\section{Conclusion}

This study showed that maternal exposure to anatase $\mathrm{TiO}_{2}$ nanoparticle caused the changes in the expression of genes associated with brain development, cell death, response to oxidative stress, and mitochondria in the 
brain during the perinatal period, and those associated with inflammation and neurotransmitters in the later stage (Figure 1). Further investigation is needed to clarify the alterations of neurotransmitter levels and motor function. This study showed also that analysis using microarray data with GO and MeSH terms can provide meaningful information, and will contribute to further interpretation of microarray results in toxicological research.

\section{Abbreviations}

cDNA: complementally DNA; DE: diesel exhaust; ED: embryonic day; GO: Gene Ontology; MeSH: Medical Subject Headings; ROS: reactive oxygen species; $\mathrm{TiO}_{2}$ : titanium dioxide.

\section{Competing interests}

The authors declare that they have no competing interests.

\section{Authors' contributions}

KT conceived the overall research idea. MS, TO, and KM carried out all procedure for animal experiments. HT, an expert on microarray analysis, had idea to apply GO and MeSH term methods for study of gene expression. MS and HT conducted the microarray analysis. MU participated substantially in the functional analysis of microarray data and drafted the manuscript. All authors read and approved the final manuscript.

\section{Additional material}

\section{Additional file 1}

Significantly enriched MeSH categories in maternal exposure group vs. control group. Additional table.

Click here for file

[http://www.biomedcentral.com/content/supplementary/17438977-6-20-S1.doc]

\section{Acknowledgements}

The authors thank Dr Tomomi Hishinuma of Research Center for Health Sciences of Nanoparticles, Tokyo University of Science for assistance in the microarray experiments, and Drs Masao Sugamata and Tomomi Ihara of Tochigi Institute of Clinical Pathology for valuable discussion. This work was supported in part by a Grant-in-Aid for Science Research from the Ministry of Education, Culture, Sports, Science and Technology of Japan, a Gland-in Aid for the Private University Science Research Upgrade Promotion Business "Academic Frontier Project and a Grant-in Aid for Health and Labour Sciences Research Grants, Research on Risk of Chemical Substances, from the Ministry of Health, Labour and Welfare".

\section{References}

I. Fujishima A, Zhang $X$, Tryk DA: $\mathrm{TiO}_{2}$ photocatalysis and related surface phenomena. Surf Sci Rep 2008, 63:5 I5-582.

2. Beydoun D, Amal R, Low G, McEvoy S: Role of nanoparticles in photocatalysis. J Nanopart Res 1999, I:439-458.
3. Jang HD, Kim SK, Kim SJ: Effect of particle size and phase composition of titanium dioxide nanoparticles on the photocatalytic properties. J Nanopart Res 200I, 3:14I-I47.

4. Gurr JR, Wang AS, Chen $\mathrm{CH}$, Jan KY: Ultrafine titanium dioxide particles in the absence of photoactivation can induce oxidative damage to human bronchial epithelial cells. Toxicology 2005, 21 3:66-73.

5. Sayes CM, Wahi R, Kurian PA, Liu Y, West JL, Ausman KD, Warheit $D B$, Colvin VL: Correlating nanoscale titania structure with toxicity: a cytotoxicity and inflammatory response study with human dermal fibroblasts and human lung epithelial cells. Toxicol Sci 2006, 92: 174- I85.

6. Oberdörster G, Oberdörster E, Oberdörster J: Nanotoxicology: An emerging discipline evolving from studies of ultrafine particles. Environ Health Persp 2005, I I 3:823-839.

7. Nel A, Xia T, Madler L, Li N: Toxic potential of materials at the nanolevel. Science 2006, 31 I:622-627.

8. Oberdörster G, Sharp Z, Atudorei V, Elder A, Gelein R, Lunts A Kreyling W, Cox C: Extrapulmonary translocation of ultrafine carbon particles following whole-body inhalation exposure of rats. J Toxicol Environ Health A 2002, 65: I53I-1543.

9. Oberdörster G, Sharp Z, Atudorei V, Elder A, Gelein R, Kreyling W, Cox C: Translocation of inhaled ultrafine particles to the brain. Inhal Toxicol 2004, 16:437-445.

10. Takeda K, Suzuki K, Ishihara A, Kubo-Irie M, Fujimoto R, Tabata M, Oshio S, Nihei $Y$, Ihara T, Sugamata M: Nanoparticles transferred from pregnant mice to their offspring can damage the genital and cranial nerve systems. J Health Sci 2009, 55:95-102.

II. Watson RE, Desesso JM, Hurtt ME, Cappon GD: Postnatal growth and morphological development of the brain: a species comparison. Birth Defects Res B Dev Reprod Toxicol 2006, 77:47 I-484.

12. Oberdörster E: Manufactured nanomaterials (fullerenes, $\mathbf{C}_{60}$ ) induce oxidative stress in the brain of juvenile largemouth bass. Environ Health Persp 2004, I I 2: I 058-I 062.

13. Tin-Tin-Win-Shwe, Yamamoto S, Ahmed S, Kakeyama M, Kobayashi T, Fujimaki H: Brain cytokine and chemokine mRNA expression in mice induced by intranasal instillation with ultrafine carbon black. Toxicol Lett 2006, 163:153-160.

14. Sugamata M, Ihara T, Takano H, Oshio S, Takeda K: Maternal diesel exhaust exposure damages newborn murine brains. J Health Sci 2006, 52:82-84.

15. Yokota S, Mizuo K, Moriya N, Oshio S, Sugawara I, Takeda K: Effect of prenatal exposure to diesel exhaust on dopaminergic system in mice. Neurosci Lett 2009, 449:38-4I.

16. Nakazato T, Takinaka T, Mizuguchi $\mathrm{H}$, Matsuda $\mathrm{H}$, Bono H, Asogawa M: BioCompass: a novel functional inference tool that utilizes MeSH hierarchy to analyze groups of genes. In Silico Biol 2007, 8:53-61.

17. Umezawa M, Tanaka N, Tainaka H, Takeda K, Ihara T, Sugamata M: Microarray analysis provides insight into early steps of pathophysiology of mouse endometriosis model induced by autotransplantation of endometrium. Life Sci 2009, 84:832-837.

18. Takeda K, Tsukue N, Yoshida S: Endocrine-disrupting activity of chemicals in diesel exhaust and diesel exhaust particles. Environ Sci 2004, I I:33-45.

19. Sugamata M, Ihara T, Sugamata M, Takeda K: Maternal exposure to diesel exhaust leads to pathological similarity to autism in newborns. J Health Sci 2006, 52:486-488.

20. Tucker KL, Meyer M, Barde YA: Neurotrophins are required for nerve growth during development. Nat Neurosci 200 I, 4:29-37.

21. Hellmich HL, Kos L, Cho ES, Mahon KA, Zimmer A: Embryonic expression of glial cell-line derived neurotrophic factor (GDNF) suggests multiple developmental roles in neural differentiation and epithelial-mesenchymal interactions. Mech Dev 1996, 54:95-105.

22. Scheepens A, Möderscheim TA, Gluckman PD: The role of growth hormone in neural development. Horm Res 2005, 64(Suppl 3):66-72.

23. Dussault JH, Ruel J: Thyroid hormones and brain development. Annu Rev Physiol 1987, 49:32I-34.

24. Oppenheimer JH, Schwartz HL: Molecular basis of thyroid hormone-dependent brain development. Endocr Rev 1997, 18:462-475.

25. Gordon N: Apoptosis (programmed cell death) and other reasons for elimination of neurons and axons. Brain Dev 1995, 17:73-77. 
26. Porter AG, Janicke RU: Emerging roles of caspase-3 in apoptosis. Cell Death Differ 1999, 6:99-104.

27. Meyer U, Engler A, Weber L, Schedlowski M, Feldon J: Preliminary evidence for a modulation of fetal dopaminergic development by maternal immune activation during pregnancy. Neuroscience 2008, 154:701-709.

28. Son GH, Chung S, Geum D, Kang SS, Choi WS, Kim K, Choi S: Hyperactivity and alteration of the midbrain dopaminergic system in maternally stressed male mice offspring. Biochem Biophys Res Commun 2007, 352:823-829.

29. Barker DJ, Gluckman PD, Godfrey KM, Harding JE, Owens JA, Robinson JS: Fetal nutrition and cardiovascular disease in adult life. Lancet 1993, 341:938-94I.

30. Xu G, Umezawa M, Takeda K: Early development origins of adult disease caused by malnutrition and environmental chemical substances. J Health Sci 2009, 55: I I-19.

Publish with Bio Med Central and every scientist can read your work free of charge

"BioMed Central will be the most significant development for disseminating the results of biomedical research in our lifetime. "

Sir Paul Nurse, Cancer Research UK

Your research papers will be:

- available free of charge to the entire biomedical community

- peer reviewed and published immediately upon acceptance

- cited in PubMed and archived on PubMed Central

- yours - you keep the copyright

Submit your manuscript here:

http://www.biomedcentral.com/info/publishing_adv.asp 